\title{
PENERAPAN SENAM KAKI DAN MODIFIKASI DIIT DALAM PENGONTROLAN KADAR GULA DARAH MELALUI METODE STUDI KASUS
}

\author{
Dely Maria $^{1)}$ \\ 1) Akademi Keperawatan Rumah Sakit Jakarta \\ Email: akperyrsj@yahoo.com
}

\begin{abstract}
ABSTRAK
Perubahan pola penyakit dari penyakit infeksi ke penyakit tidak menular (PTM) merupakan faktor utama masalah morbiditas dan mortalitas. Menurut WHO (2013), 80\% penderita DM berasal dari negara berkembang salah satunya Indonesia. Berdasarkan hasil data Riskesdas (2013), 5,7\% di Indonesia khususnya Jakarta timur yang terkena DM dari usia 15 tahun memiliki prevalensi sebesar 2,4\%. Berbagai masalah dapat timbul bila diabetes melitus tidak ditangani seperti neuropati dan retinopati. Metode yang digunakan yaitu studi kasus. Studi kasus dilakukan pada 2 pasien DM yang mengalami ketidakefektifan perfusi jaringan perifer, dengan tujuannya melaksanakan asuhan keperawatan keluarga Ibu S dan Ibu M yang mengalami diabetes melitus dengan ketidakefektifan perfusi jaringan perifer di Rw 03 Rt 02 dan Rw 04 Rt 06 Kelurahan Pondok Kopi I Jakarta Timur. Studi kasus ini dilakukan 9x kunjungan selama 9 hari dalam pengaturan pola diit DM dan senam kaki sebanyak 9 kali pada pasien I dan 9 kali pada pasien II. Kesimpulannya : pada kasus I (keluarga Ibu S) terjadi penurunan GDS sebesar $75 \mathrm{mg} / \mathrm{dl}$ dari 250 mg/dl dan kasus II (keluarga Ibu M) terjadi penurunan GDS sebesar 156 mg/dl dari 346 mg/dl. Hal ini menunjukkan adanya pengaruh senam kaki terhadap penurunan kadar glukosa serta peningkatan sensitivitas pada kaki pada kedua kasus.
\end{abstract}

Kata kunci: Diabetes Melitus, Diit, Perfusi Jaringan Perifer, Senam Kaki

\begin{abstract}
Changes in the pattern of diseases from infectious diseases to non-communicable diseases (PTM) are a major factor in the problem of morbidity and mortality. According to WHO (2013), 80\% of DM patients come from developing countries, one of them is Indonesia. Based on the results of Riskesdas (2013) data, 5.7\% in Indonesia had DM from the age of 15 years, the prevalence of DM in East Jakarta was 2.4\%. Problems can arise when diabetes mellitus is not treated such as neuropathy and retinopathy. The method used is the case study method. This case study was carried out on 2 DM patients who experienced ineffectiveness of peripheral tissue perfusion, with the aim of implementing family nursing care Mrs. S and Mrs. M who had diabetes mellitus with ineffectiveness of peripheral tissue perfusion in Rw 03 Rt 02 and Rw 04 Rt 06 Pondok Kopi I Jakarta District East. This case study was conducted 6 times for 6 days in setting DM diit pattern and foot exercises 6 times in patients I and 8 times in patients II. As a result, in case I there was a decrease in GDS of $75 \mathrm{mg} / \mathrm{dl}$ from $250 \mathrm{mg} / \mathrm{dl}$ and case II there was a decrease in GDS of 156 $\mathrm{mg} / \mathrm{dl}$ from $346 \mathrm{mg} / \mathrm{dl}$, indicating an effect of decreased glucose levels and increased sensitivity of the feet in both cases.
\end{abstract}

Keywords: Diabetes Melitus, Diit, Foot Gymnastics, Peripheral Tissue Perfusion 


\section{PENDAHULUAN}

Terjadinya transisi epidemiologi yang paralel dengan transisi demografi dan transisi teknologi di Indonesia dewasa ini telah mengakibatkan perubahan pola penyakit, dari penyakit infeksi ke penyakit tidak menular (PTM) meliputi penyakit degeneratif yang merupakan faktor utama masalah morbiditas dan mortalitas. Diabetes disebut the silent killer karena hampir sepertiga orang dengan diabetes tidak mengetahui mereka menderita diabetes melitus.

Prevalensi DM di Indonesia berdasarkan hasil pengukuran kadar gula darah pada penduduk umur lebih dari lima belas tahun di daerah perkotaan adalah sebesar 5,7\%. Jakarta Timur merupakan salah satu kotamadya di propinsi DKI Jakarta yang memiliki angka prevalensi DM Tipe 2 sebesar 2,4\%. (Riskesdas, 2013). Tahun 2030 Prevalensi Diabetes Melitus Di Indonesia mencapai 21,3 juta orang. (www.dinkes.net/2014). Berdasarkan data dari Dinas Kesehatan di Jakarta pada tahun 2014, Diabetes Melitus menempati urutan ke 3 dari 11 penyakit yang menular sebanyak 360 jiwa penderita $(0,4 \%)$ DM tipe 1 atau disebut juga Diabetes tergantung insulin (DMTI) atau non Insulin Dependen Diabetes Melitus (IDDM). Data dari Puskesmas Pondok Kopi I pada tiga bulan terakhir dari Maret sampai Mei 2017 berjumlah 58 orang dari 5335 pasien $(1,08 \%)$ yang menderita diabetes melitus.

Upaya kemenkes dalam mengelola PTM termasuk diabetes melitus, yaitu: mengembangkan dan memperkuat kegiatan deteksi dini diabetes melitus secara aktif (skrinning), meningkatkan akses masyarakat terhadap pelayanan deteksi dini melalui kegiatan Posbindu PTM, meningkatkan akses penderita terhadap pengobatan diabetes mellitus melalui revitalisasi puskesmas untuk mengendalikan PTM. Melalui peningkatan sumber daya tenaga kesehatan yang professional dan kompeten dalam upaya pengendalian PTM, khususnya tatalaksana PTM di fasilitas pelayanan kesehatan dasar seperti puskesmas: melalui peningkatan manajemen pelayanan pengendalian PTM secara komprehensif (terutama promotif dan preventif) dan holistik, serta peningkatan ketersediaan sarana dan prasarana promotif dan preventif, maupun sarana prasarana diagnostik dan pengobatan. 
Perawatan diabetes melitus ditimbulkan oleh penyakit DM dapat berhubungan dengan perilaku terhadap diminimalisir.

keluarga penderita diabetes melitus, dimana keluarga dapat menjadi faktor yang sangat berpengaruh dalam menentukan program perawatan, karena keluarga berfungsi sebagai system pendukung bagi anggota yang menderita diabetes melitus. Untuk menciptakan suatu kondisi yang sehat dan terkontrol, maka keluarga diharapkan mempunyai pengetahuan tentang penyakit diabetes melitus agar tercipta suatu perilaku perawatan yang tepat dalam hal pencegahan, penatalaksanaan pada penderita diabetes melitus. (American Diabetes Association, 2012).

Keluarga akan mempengaruhi kualitas hidup pada penderita DM, dimana terdapat hubungan yang kuat antara keluarga dan status kesehatan anggotanya. Peran keluarga sangat penting bagi setiap aspek perawatan kesehatan anggota keluarga, mulai dari mengenal masalah kesehatan hingga pemanfaatan fasilitas kesehatan. Jika peran keluarga diperankan dengan baik dalam penatalaksanaan penderita DM maka komplikasi akut yang dapat

Sebuah penelitian mengemukakan berjumlah 42 responden (75\%) dari 56 responden, mengalami penurunan kadar gula darah dikarenakan melakukan senam kaki dengan baik dan benar secara teratur dan relatif memiliki nilai kadar gula darah $<200$ $\mathrm{mg} / \mathrm{dl}$. Sedangkan 14 responden $(25 \%)$ dari 56 responden memiliki kadar gula darah $\geq 200 \mathrm{mg} / \mathrm{dl}, \quad 7$ responden diantaranya kadar gula turun tetapi masih >200 mg/dl, untuk 5 orang lainnya kadar gulanya tetap (tidak naik 
ataupun turun) dan 2 orang sisanya kadar gulanya mengalami peningkatan. Hal ini disebabkan oleh faktor usia, pola diet dan motivasi. (Ruben, G., Julia, V. R., \& Michael, Y. K. (2013)

Upaya pengendalian komplikasi tidak hanya dari faktor keluarga, namun peran perawat pun dapat membantu menyelesaikan masalah. Peran perawat dalam mengatasi masalah diabetes melitus adalah sebagai edukator, konselor, dan care giver.

Peran perawat sebagai edukator yaitu untuk membantu meningkatkan dalam tingkat pengetahuan tentang diabetes melitus dengan memberikan penyuluhan. Peran perawat sebagai konselor yaitu memberikan alternatifalternatif dalam pemecahan masalah kesehatan seperti mengajarkan senam kaki, makanan yang dianjurkan dalam satu kali porsi makan agar penderita diabetes melitus dapat mengontrol gula daranya. Peran perawat sebagai yang digunakan dalam penelitian ini adalah studi kasus untuk mengeksplorasi masalah asuhan keperawatan pada keluarga yang mengalami Diabetes Melitus dengan ketidakefektifan perfusi jaringan perifer di wilayah
Puskesmas Kelurahan Pondok Kopi I Jakarta Timur.

Subjek yang digunakan adalah 2 keluarga yaitu masalah keperawatan ketidakefektifan perfusi jaringan perifer dan diagnosis medis Diabetes Melitus. Penetapan masalah ketidakefektifan perfusi jaringan perifer care giver yaitu untuk menberikan pelayanan keperawatan kepada individu, keluarga, kelompok atau masyarakat sesuai diagnosis masalah yang terjadi mulai masalah yang bersifat sederhana sampai pada masalah yang kompleks

\section{METODE}

dengan melakukan kajian terhadap ekstremitas bawah partisipan. Dimana keluhan yang dirasakan sering baal, kesemutan. Kedua partisipan memiliki masalah keperawatan dan diagnosis medis yang sama. Kriteria inklusi partisipan yang dilakukan modifikasi diit adalah partisipan yang sudah mengetahui tentang makanan yang harus dipantang namun tidak pernah makanan yang diperbolehkan untuk penderita DM. 
Metode pengumpulan data yang digunakan adalah Wawancara ( data dasar keluarga, lingkungan, struktur keluarga, fungsi keluarga, stress dan koping keluarga, harapan keluarga terhadap asuhan keperawatan keluarga, dan fungsi perawatan kesehatan). Observasi dan pemeriksaan fisik data dasar keluarga, lingkungan, struktur keluarga, fungsi keluarga, stress dan koping keluarga, harapan keluarga terhadap asuhan keperawatan keluarga, dan fungsi perawatan kesehatan.

Data dikumpulkan dari hasil wawancara dan observasi. Hasil ditulis dalam bentuk catatan lapangan dan disalin secara struktur. Instrumen menggunakan kajian asuhan keperawatan keluarga dan kajian khusus mengarah ke masalah kesehatan Diabetes Melitus. Setelah itu data dikelompokkan menjadi data subjektif dan data objektif, diagnosis dan dibandingkan hasil yang normal. Penyajian data dilakukan dengan tabel. Kerahasiaan klien sangat dijaga dengan cara membuat initial pada nama klien. Dari data yang disajikan kemudian data tersebut dibahas dan dibandingkan dengan hasil penelitian terdahulu dan secara teoritis.

\section{HASIL}

Tipe keluarga Bpk S dan Bpk I adalah keluarga besar, pada Bpk S di dalam satu rumah terdiri dari keluarga inti dan orang-orang yang berhubungan yaitu Bapak S, An. O, Ibu M dan An. K. Lalu pada Bpk I satu rumah terdiri dari keluarga inti dan orang-orang yang berhubungan yaitu Bpk M, Ibu M, Ibu K, An.A, dan An.K. Tahap perkembangan keluarga Bpk $\mathrm{S}$ adalah tahap perkembangan keluarga pelepasan, pada keluarga Bpk I adalah tahap perkembangan keluarga dengan anak dewasa, dan semua tugas perkembangan sudah terpenuhi. Lingkungan rumah Bpk S dan Bpk I pada umumnya bersih, tetangga sekitar rumah Bpk S dan Bpk I adalah pribumi dan pendatang. Terdapat sistem pendukung dari keluarga dan tetangga sekitar serta kelompok pengajian Ibu S dan Ibu M, lalu kelompok arisan pada Ibu M. Pola komunikasi keluarga Bpk S dan Bpk I baik, tidak ada emosi dalam penyampaian pendapat. Pada keluarga Bpk S dan Bpk I pengambilan keputusan ada pada Bpk S dan Bpk I, tidak ada peran informal yang dijalankan keluarga Bpk S dan Bpk I. 
Fungsi afektif dalam keluarga Bpk S dan Bpk I, pada saat keluarga mengalami peningkatan kadar gula, upaya keluarga yaitu mengingatkan dan memotivasi dalam kepatuhan mengkonsumsi menu diit yang telah dianjurkan. Fungsi sosialisasi dalam keluarga Bpk S dan Bpk I, pada saat Ibu $\mathrm{S}$ dan Ibu $M$ mengalami kekambuhan pada penyakitnya, keluarga dapat mengambil keputusan untuk melakukan pemeriksaan ke pelayanan kesehatan terdekat. Fungsi reproduksi keluarga Bpk S dan Ibu I memiliki 3 anak, terdiri dari 1 perempuan dan 2 laki - laki. Bpk S memiliki 4 cucu, dan Bpk I memiliki 3 cucu. Di sekitar rumah Bpk S dan Bpk I terdapat fasilitas kesehatan seperti puskesmas pondok kopi I. Dan fasilitas kesehatan Bpk $\mathrm{S}$ seperti posyandu lansia, Bpk I puskesmas pondok kopi II. Ibu S menggunakan pelayanan kesehatan karena terjangkau dari rumah.

Kedua partisipan (Ibu S dan Ibu M) memiliki riwayat penyakit DM. Ibu S sejak 1 tahun yang lau sedangkan Ibu M 2 tahun yang lalu. Hasil GDS Ibu S $335 \mathrm{mg} / \mathrm{dL}$, sedangkan Ibu M 320 $\mathrm{mg} / \mathrm{dL}$.
Pengobatan tradisional yang sudah dilakukan Ibu S dan Ibu $\mathrm{M}$ adalah mengkonsumsi jus daun binahong. Daun binahong memiliki kandungan senyawa aktif flavonoid berguna untuk menurunkan kadar gula darah dan mampu bertindak sebagai penangkap radikal bebas. Ibu $\mathrm{S}$ juga mengkonsumsi jus daun afrika, yang mengandung lakton seskuiterpen untuk mengobati diabetes awal dan mengurangi kesemutan. Kemudian Ibu $\mathrm{M}$ juga mengkonsumsi rebusan daun salam memiliki kandungan senyawa flavanoid yang berguna untuk menurunkan kadar gula darah dan mampu bertindak sebagai penangkap radikal hidroksil.

Pengkajian fungsi perawatan kesehatan Ibu S didapatkan data Ibu S: ibu $\mathrm{S}$ belum mengetahui tentang penyakit DM, Ibu S merasa mudah lelah, sering minum dan pipis,bila ada luka sulit kering. Ibu $\mathrm{S}$ tidak mengetahui bahwa gejala yang dirasakan adalah gejala DM. Ibu S selama ini memeriksakan dirinya ke Puskesmas dan mendapatkan data obat Metformin $3 \times 1$ tab. Ibu $\mathrm{S}$ juga tidak pernah mengkonsumsi obat tradisional. Ibu $\mathrm{S}$ mengetahui pentingnya penggunaan sandal (alas 
kaki) pada saat keluar rumah . Ibu $\mathrm{S}$ mengatakan tidak pasrah dengan keadaannya, sehingga ibu $\mathrm{S}$ selalu memeriksakan dirinya ke Puskesmas. Namun Ibu $\mathrm{S}$ belum mengetahui perawatan mendalam mengenai DM.

Fungsi perawatan kesehatan pada Ibu M, didapatkan data : Ibu M mengatakan sudah mengetahui penyakitnya namun belum secara mendalam. Ibu M mengatakan keluahannya yaitu saat gula nya tinggi pandangannya buram, sering pipis pada malam hari, tidak nafsu makan. Terkadang tangan dan kaki baal, dan gatal. Ibu M tidak pasrah dengan keadaannya sehingga datang ke puskesmas untuk berobat. Ibu $\mathrm{M}$ mendapatkan obat Metformin 500mg 3x1 tab. Ibu M tidak mengetahui akibat lanjut jika DM tidak ditangani. Keluarga tidak mengetahui tentang perawatan dirumah.

Masalah keperawatan yang diselesaikan pada kedua keluarga ini adalah ketidakefektifan perfusi jaringan perifer. Masalah keperawatan diambil dari data secara wawancara, fisik terutama fungsi perawatan kesehatan.

\section{PEMBAHASAN}

Penyebab DM Tipe I yang ditemukan pada kasus Diabetes Melitus Ibu S yaitu keturunan dan obesitas. Lalu penyebab DM Tipe II pada Ibu M yaitu riwayat keluarga. Penyebab yang tidak ditemukan pada Ibu S dan Ibu M yaitu faktor-faktor imunologi, faktor lingkungan, usia. Lalu untuk penyebab yang tidak ditemukan pada Ibu $S$ yaitu riwayat keluarga. Hal ini dibuktikan pada saat pengkajian tidak ditemukan yaitu faktor-faktor imunologi, faktor lingkungan, usia, dan riwayat keluarga.

Imunologi dapat terjadi apabila adanya respon autoimun yang mengarah untuk terjadinya reaksi yang asing pada jaringan normal tubuh, namun pada kasus tidak ada data yang mengarah untuk terjadinya masalah dikarenakan kondisi kesehatan keluarga dalam batas normal. Etiologi riwayat keluarga terjadi pada anggota keluarga dekat pasien diabetes tipe II dan pada kembar non identik, resiko menderita penyakit ini lebih besar dari pada subjek dengan usia dan berat yang sama, yang tidak memiliki riwayat penyakit dalam keluarganya. Tidak seperti diabetes tipe I, penyakit ini tidak berkaitan dengan HLA. Sehingga pada kasus tidak 
ditemukan data penunjang untuk masalah, karena pasien menderita DM Tipe I dan di dalam keluarga Ibu S tidak ada yang memiliki riwayat penyakit yang sama.

Faktor lingkungan dapat terjadi apabila adanya virus atau toksin tertentu yang dapat memicu terjadinya proses autoimun yang dapat menimbulkan kerusakan sel beta pada pankreas, namun pada kasus tidak ditemukan data yang menunjang untuk terjadinya masalah karena pada kasus lingkungan dalam kondisi baik.

Etiologi usia masuk kategori resistensi insulin cenderung meningkat pada usia diatas 65 tahun, namun pada kasus tidak ditemukan data yang menunjang untuk terjadinya masalah, karena pada kasus ditemukan kategori usia 54 tahun dan 48 tahun. Lalu etiologi obesitas terjadi karena insulin yang tersedia menjadi kurang efektif dalam meningkatkan efek metabolik, pada kasus tidak didapatkan data yang menunjang masalah karena IMT Ibu M 21,4 (Normal).

Tanda dan gejala DM yang tidak ditemukan pada Ibu $\mathrm{S}$ dan Ibu $\mathrm{M}$ adalah polifagia, kulit gatal, penurunan
BB dan ketonuria. Pada Ibu S tidak ditemukan data penglihatan kabur. Dan pada Ibu M tidak ditemukan data mudah lelah. Berdasarkan proses penyakit polifagia dapat terjadi karena meningkatnya proses katabolisme lalu adanya pemecahan glikogen menjadi energi dan hal ini dapat menstimulasi pusat lapar, pada kasus tidak terdapat data yang menunjang terjadinya tanda gejala tersebut karena pada kasus nafsu makan Ibu S dan Ibu M mengalami penurunan namun untuk tetap memenuhi kebutuhan nutrisinya keluarga pun memberikan dorongan agar makan sedikit tapi sering. Lalu penurunan berat badan tidak terjadi selama pengambilan kasus dilaksanakan, karena pada Ibu S dan Ibu M pada kasus BB nya tetap $65 \mathrm{~kg}$ dan $55 \mathrm{~kg}$.

Tanda gejala kulit gatal dapat terjadi pada saat peningkatan kadar gula dapat mengakibatkan penumpukan pula pada kulit dikarenakan bakteri yang sudah menyerang pada, karena pada kasus tidak ditemukan keluhan kulit gatal pada Ibu S dan Ibu $\mathrm{M}$ tidak pernah merasakan adanya kelainan pada kulitnya. 
Begitu juga dengan tanda gejala ketonuria dapat terjadi pada saat glukosa tidak digunakan untuk energi maka akan menggunakan asam lemak yang akan di ubah menjadi energi, sedangkan pada kasus tidak dilakukan pemeriksaan ketonurine pada Ibu S dan Ibu M. Adapun tanda gejala penglihatan kabur dapat terjadi apabila kadar gula mengalami peningkatan sehingga suplai oksigen ke mata menjadi berkurang, namun pada kasus tidak ditemukan data yang menunjang terjadinya masalah karena pada Ibu S fungsi penglihatannya masih dalam kondisi baik. Kemudian tanda dan gejala mudah lelah dapat terjadi karena kurangnya cadangan energy yang terdapat dalam tubuh sehingga adanya rasa kelaparan pada sel akibat kehilangan potassium, pada kasus tidak terdapat data yang menunjang terjadinya tanda dan gejala karena selama melakukan aktivitas baik sebagai Ibu Rumah Tangga maupun Kader Ibu M selalu dalam kondisi prima.

Pada Ibu S dan Ibu M ditemukan komplikasi yaitu neuropati. Neuropati terjadi karena sirkulasi darah terhambat sehingga suplai darah ke perifer mengalami penurunan. Saat dilakukan pengkajian, Ibu S mengatakan kakinya masih merasa baal dan Ibu M mengatakan tangan dan kakinya merasa baal/kesemutan. Saat dilakukan pengukuran TD Ibu S 130/80 mmHg dan Ibu M TD 120/80 mmHg, dan tidak ada keluhan lainnya.

Tidak ditemukan adanya komplikasi lainnya, hal ini dibuktikan dengan tidak terjadi gagal jantung, gagal ginjal, stroke, gangguan penglihatan, gangren/ulkus diabetik. Komplikasi gagal jantung dapat terjadi karena adanya gangguan fungsi jantung karena aterisklerosis, dan pada kasus dalam organ jantung fungsinya masih dalam batas normal seperti Ibu $\mathrm{S}$ hasil pemeriksaan TTV: TD 130/80 $\mathrm{mmHg}$ dan Nadi $75 \mathrm{x} /$ menit, kemudian pada Ibu M hasil pemeriksaan TTV: TD 120/80 mmHg dan Nadi 78x/menit.

Gagal ginjal dapat terjadi karena suplai oksigen ke ginjal menjadi terhambat, pada kasus tidak ditemukan tanda gejala untuk menunjang terjadinya masalah karena tidak ada keluhan pada fungsi ginjalnya seperti nyeri pada daerah pinggang. Stroke dapat terjadi karena adanya hambatan pembuluh 
darah pusat, tidak ada data yang menunjang untuk terjadinya masalah karena pada kasus tidak ada yang mengalami muntah proyektil, edema papil dan pusing.

Gangguan penglihatan dapat terjadi karena suplai oksigen ke retina sehingga mengalami kebutaan, tidak ada data yang menunjang untuk terjadinya masalah karena fungsi penglihatannya masih dalam batas normal, hanya saja penglihatan Ibu M sudah mulai kabur namun masih bisa melihat dengan jarak yang cukup dekat sekitar 2 meter.

Gangren/ulkus diabetik dapat terjadi karena adanya penurunan sintesis protein yang dapat mengakibatkan terjadinya mudah infeksi dan luka sulit sembuh, tidak ditemukan data yang menunjang untuk terjadinya masalah karena pada kasus daerah ekstremitas bawah dalam keadaan normal dan tidak terdapat luka.

Ibu $\mathrm{S}$ dan Ibu $\mathrm{M}$ tidak melakukan pemeriksaan diagnostik lainnya yang berkaitan dengan Diabetes Melitus. Selama ini Ibu S dan Ibu M hanya memeriksa nilai gula darah sewaktu saja. Penatalaksanaan farmakologis yang sudah dilakukan oleh $\mathrm{Ibu} S$ dan Ibu M adalah mengkonsumsi obat metformin, obat ini bekerja langsung pada hepar untuk menurunkan produksi glukosa hati dengan jalan glukoneogenesis tanpa meningkatkan sekresi insulin dari sel beta pankreas. Riwayat genetik Ibu S dan Ibu M, terjadi karena kerusakan sel beta pankreas yang diakibatkan defisensi insulin hal ini dapat mengakibatkan terjadinya kenaikan kadar glukosa menghambat suplai oksigen ke perifer menjadi lambat.

Penatalaksanaan farmakologis yang tidak dilakukan oleh Ibu $\mathrm{S}$ adalah pemberian insulin, hal ini dikarenakan kadar gula darah pada Ibu $\mathrm{S}$ dapat terkontrol dengan pemberian obat oral. Penatalaksaan ini sebenarnya belum tepat bila disesuaikan dengan penyebab DM yang terjadi pada Ibu $S$, namun karena ada rasa percaya mengenai adat keluarga apabila pergi ke pelayanan kesehatan seperti puskesmas. Padahal Ibu $\mathrm{S}$ tidak pernah mengalami pengalaman yang kurang baik dari petugas pelayanan kesehatan. Pada saat kunjungan rumah kelima Ibu S ditanya kembali karena pada hari itu obat persediaaanya habis, maka Ibu $\mathrm{S}$ 
bersedia pergi ke pelayanan kesehatan diantar oleh Bapak S. Mulai hari itu terapi yang didapat sesuai dengan penyebab DM yang dialaminya.

Pada Ibu M dapat terkontrol dengan pemberian obat oral sehingga tim kesehatan belum memberikan terapi insulin. Penatalaksanaan non farmakologis yang tidak dilakukan Ibu $\mathrm{S}$ dan Ibu M adalah management diet, dan latihan fisik. Hal ini dikarenakan kurangnya pengetahuan Ibu S dan Ibu M terhadap pengobatan yang dibutuhkan.

Dari pengkajian yang didapat, tidak ditemukan adanya cara keluarga mengatasi masalah secara maladaptif seperti mengeluarkan emosi. Pada penjajakan tahap II yang berhubungan dengan lima tugas keluarga yang dilakukan pada keluarga Bpk $\mathrm{S}$ dan Bpk I ditemukan data keluarga Bpk S dan Bpk I belum mengenal masalah kesehatan yang dialami. Hal ini dibuktikan keluarga Bpk $\mathrm{S}$ belum mengetahui tentang DM dan pada keluarga Bpk I tidak mengetahui terlalu dalam tentang DM. Keluarga Bpk S dan Bpk I belum mengetahui pengertian, penyebab, tanda gejala, pencegahan, dan akibat lanjut Diabetes Melitus. Ibu S dan Ibu $M$ sudah mampu mengambil keputusan untuk merawat dirinya yaitu dengan memeriksakan dirinya ke puskesmas pondok kopi I. Bpk S dan Bpk I mampu merawat masalah kesehatan Ibu $\mathrm{S}$ dan Ibu $\mathrm{M}$ dengan mengingatkan untuk minum obat. Keluarga Bpk S dan Bpk I belum banyak memahami modifikasi lingkungan yang dibutuhkan untuk Ibu S dan Ibu M, hal ini dibuktikan saat di rumah maupun di luar rumah menggunakan alas kaki. Untuk pemanfaatan fasilitas kesehatan, keluarga sudah menggunakan fasilitas kesehatan yang ada.

Perencanaan keperawatan keluarga di analisis dari pengkajian yang bersifat suplemental, fasilitatif maupun developmental. Tipologi perencanaan keperawatan keluarga dibedakan menjadi perencanaan suplemental, fasilitatif maupun developmental. Domain intervensi terdiri dari kognitif, afektif dan psikomotor.

Pelaksanaan tindakan keperawatan dilakukan sesuai dengan perencanaan yaitu sebanyak 9 kali kunjungan rumah selama 9 hari (tanggal 14 oktober -22 
oktober 2017). Kunjungan pertama melakukan TUK I dan TUK II (kemampuan keluarga mengenal dan mengambil keputusan) dengan waktu kunjungan 30 menit. Pelaksanaan yang penulis lakukan sesuai dengan intervensi TUK I dan TUK II yaitu mendiskusikan dengan keluarga tentang pengertian, klasifikasi, penyebab, tanda dan gejala, pencegahan, akibat lanjut diabetes mellitus. Memotivasi keluarga untuk mengidentifikasikan faktor-faktor yang menyebabkan diabetes mellitus pada Ibu S dan Ibu M dan tanda gejala yang dirasakan Ibu S dan Ibu M, melakukan evaluasi tentang yang sudah dijelaskan, motivasi keluarga untuk merawat anggota keluarga yang menderita diabetes melitus, memberikan reinforcement positif. Saat dilakukan evaluasi, keluarga mampu menyebutkan kembali sesuai dengan standar yang sudah ditetapkan. Tindakan tersebut sesuai dengan intervensi yang sudah ditegakkan.

Kunjungan kedua pada kasus I melakukan TUK III (kemampuan keluarga merawat) dengan waktu kunjungan 55 menit. Penulis melakukan redemonstrasi senam kaki sebanyak 2x. Sedangkan pada kasus II melakukan TUK III dengan waktu kunjungan 30 menit, waktu pelaksanaan sesuai dengan perencanaan yaitu 30 menit. Pelaksanaan yang penulis lakukan sesuai dengan intervensi TUK III yaitu mengevaluasi TUK I dan TUK II, mendiskusikan dengan keluarga cara perawatan DM dirumah, motivasi keluarga untuk merawat anggota keluarga yang sakit dirumah, ajarkan cara senam kaki DM dan menu diit DM, berikan reinforcement positif. Saat dilakukan evaluasi, Ibu S dan Ibu M mampu melakukan demonstrasi kembali senam kaki DM dan menu diit DM dan menyebutkan kembali sesuai dengan standar. Tindakan yang diberikan sudah sesuai dengan intervensi yang disusun.

Kunjungan ketiga pada kasus I dan II dengan waktu kunjungan 10 menit. Pada saat kunjungan dilakukan evaluasi kadar gula darah. Karena pada saat pelaksanaan TUK III belum dilakukan pemeriksaan Gula Darah Sewaktu.

Kunjungan keempat kasus I dan kasus II yaitu TUK IV dan TUK V (kemampuan keluarga memodifikasi 
lingkungan dan memanfaatkan pelayanan kesehatan) dengan waktu 30 menit. Pelaksanaaan yang penulis lakukan pada TUK IV dan TUK V yaitu mengevaluasi TUK III, menjelaskan pada keluarga cara melakukan modifikasi lingkungan yang tepat pada penderita diabetes melitus dan menjelaskan manfaat pelayanan kesehatan, memotivasi keluarga untuk menyebutkan kembali cara modifikasi lingkungan dan manfaat pelayanan kesehatan, memberikan reinforcement positif. Saat dilakukan evaluasi, keluarga mampu menyebutkan kembali yang sudah dijelaskan sesuai dengan standar yang ditentukan. Kemudian pada saat kunjungan berlangsung, dilakukan pula monitor GDS, Senam Kaki dan Menu diit.

Kunjungan kelima terhadap kasus I dan II dengan waktu 20 menit, untuk memonitor GDS, Senam Kaki dan Menu diit. Kunjungan ke enam kasus I dan II dengan waktu 20 menit, untuk memonitor GDS, Senam Kaki dan Menu diit. Kunjungan ke tujuh kasus I dan II dengan waktu 20 menit, untuk memonitor GDS, Senam Kaki dan Menu diit. Kunjungan ke delapan kasus I dan II dengan waktu 20 menit, untuk memonitor GDS, Senam Kaki dan Menu diit. Kunjungan ke sembilan kasus I dan II dengan waktu 20 menit, untuk memonitor GDS, Senam Kaki dan Menu diit.

dianjurkan.

Monitoring penerapan senam kaki dan modifikasi diit

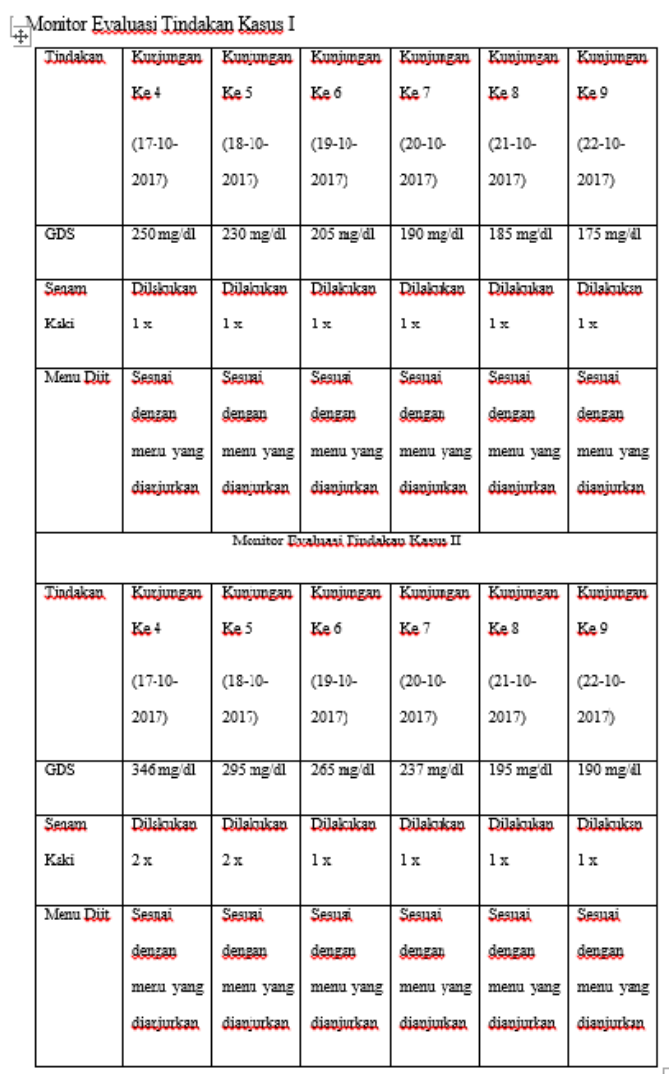

\section{KESIMPULAN}

Penerapan senam kaki DM secara umum keluarga mampu mengatasi masalah ketidakefektifan perfusi jaringan perifer pada Ibu $S$, tetapi masalah belum teratasi. Dikarenakan 
Ibu $\mathrm{S}$ masih merasa baal pada tangan, kaki dan GDS 175 mg/dl. Ibu S sudah melakukan modifikasi lingkungan seperti menghindari stress karena ia mengasuh cucu. Pada Ibu M masalah belum teratasi karena Ibu $\mathrm{M}$ masih merasa baal pada tangan dan kakinya dan GDS 190 mg/dl dan Ibu M sudah melakukan modifikasi lingkungan seperti mengurangi konsumsi tinggi glukosa dan memanfaatkan fasilitas kesehatan pada saat persediaan obatnya habis langsung datang ke pelayanan kesehatan.

Berdasarkan hasil monitor didapatkan perbandingan pada kasus I dengan DM tipe I dan kasus II dengan DM tipe II. Evaluasi monitoring GDS pada kasus I terjadi penurunan GDS sebesar 75 mg/dl dari 250 mg/dl dan pada kasus II terjadi penurunan GDS sebesar 156 mg/dl dari $346 \mathrm{mg} / \mathrm{dl}$. Hal ini terjadi bahwa senam kaki yang dilakukan pada Ibu M lebih banyak dibandingkan dengan Ibu S, maka akan mempengaruhi tingkat sensitivitas pada daerah perifer dan perubahan kadar gula pada masing-masing pasien. Dikarenakan hal tersebut diharapkan partisipan melakukan secara rutin senam kaki dan modifikasi diit untuk kestabilan gula darah. Keluarga juga sebagai motivator dalam melakukan tindakan yang positif untuk kesembuhan pasien (partisipan).

\section{UCAPAN TERIMAKASIH}

1. Kepala Puskesmas Pondok Kopi II yang sudah memberikan ijin melakukan penelitian di wilayah

2. Direktur Akademi Keperawatan Rumah Sakit Jakarta yang sudah memberikan kesempatan untuk melakukan penelitian

\section{DAFTAR PUSTAKA}

Aldyningtyas, F., Tito, P., \& Harjono. (2012). Sistem pendukung keputusan penghitung kalori diet bagi diabetesi. Jurnal Informatika. Vol. II No. 2. ISSN 2086-9398. Pp. 145-157. Diakses Pada Tanggal 05 Juni 2017 Pukul 10.26 WIB

Andra, S \& Yessie, MP, (2013). KMB 2 Keperawatan medikal bedah (keperawatan dewasa). Yogyakarta: Nuha Medika

Brunner \& Suddarth, (2013). Keperawatan Medikal Bedah Edisi 12. Jakarta: EGC

Harmoko, (2012). Asuhan keperawatan keluarga. Yogyakarta: Pustaka Pelajar

Nanda Internasional, (2015). Diagnosis keperawatan definisi \& klasifikasi 2015-2017 Edisi 10. Jakarta: EGC 
Nur Aini \& Ledy, MA, (2016). Asuhan keperawatan pada sistem endokrin dengan pendekatan NANDA NIC NOC. Jakarta: Salemba Medika

Padila, (2012). Buku ajar: keperawatan medikal bedah. Yogyakarta: Nuha Medika

Padila, (2012). Buku ajar: keperawatan keluarga. Yoyakarta: Nuha Medika

Risma, W., Ni Ketut, G. P., \& I Putu, A. (2014). Pengaruh kombinasi pengetahuan pola diit $d m$ dan senam diabetes terhadap kadar gula darah pada pasien DM Tipe II. Jurnal Ilmu Keperawatan FK UNUD. ISSN 2303-1298. Diakses pada tanggal 03 Juni 2017 Pukul 16.34 WIB.

Ruben, G., Julia, V. R., \& Michael, Y. K. (2016). Pengaruh senam kaki diabetes terhadap perubahan kadar gula darah pada pasien DM Tipe 2 di wilayah kerja puskesmas enemawira. eJournal Keperawatan (eKp). Vol. 4 No. 1 pp. 1-5 Diakses pada tanggal 1 Juni 2017 pukul 10.28 WIB

Santun, S \& Agus, CD, (2008). Penuntun praktis asuhan keperawatan keluarga. Jakarta: TIM

Setiadi, (2008). Konsep \& proses keperawatan keluarga. Yogyakarta: Graha Ilmu

Surawan, F. E. D., \& Zulman, E. (2012). Pengaruh ekstrak jus segar dan rebusan pare
(Momordica Charantia L.) terhadap tikus diabetes. Jurnal Agroindustri. Vol. 2 No. 1 pp. 30-35. ISSN 2088-5369. Diakses Pada Tanggal 31 Mei 2017 Pukul 08.30 WIB.

Tarwoto et.al. (2012). Keperawatan medikal bedah gangguan sistem endokrin. Jakarta. Trans info Media

www.depkes.go.id diakses pada $09 \mathrm{Mei}$ 2017

www.dinkes.net/2014 diakses pada 09 Mei 2017

www.hukor.depkes.go.id diakses pada 08 Desember 2016

www.Kemenkes.com diakses pada 09 Mei 2017

www.Riskesdas.com diakses pada 09 Mei 2017

www.who.com diakses pada 09 Mei 2017 